\title{
Bacteriocin: the avenues of innovation towards applied microbiology
}

\author{
Hira Hashim, Shomaila Sikandar, Muhammad Amjad Khan and Aisha \\ Waheed Qurashi*
}

Department of biology, Lahore Garrison University DHA phase-VI Lahore-Pakistan

*Corresponding author's email: aishawaheedqureshi@lgu.edu.pk

Citation

Hira Hashim, Shomaila Sikandar, Muhammad Amjad Khan and Aisha Waheed Qurashi. Bacteriocin: the avenues of innovation towards applied microbiology. Pure and Applied Biology. Vol. 8, Issue 1, pp460-478. http://dx.doi.org/10.19045/bspab.2018.700205

Received: 11/09/2018 Revised: 29/11/2018

Accepted: $30 / 11 / 2018$

Online First: 12/12/2018

\section{Abstract}

Microbial adhesion and pathogenesis result in serious problems in world. In case of infectious diseases in human being, there is an epidemiological issue, on another hand, if microbes infect poultry and crops, there is a huge economical and nutritional loss. Antibiotics used to control this microbial pathogenesis but the excess use of antibiotics and other chemical compounds in intensive animal production have several side effects and results in increased antibiotic resistance day by day. Antimicrobial resistance becomes a great problem in the world. Scientists are seeking for the product which can be used as alternative to the antibiotic with less side effects. Bacteriocin is such a type of peptide which works when bacteria become resistant to some antibiotic. It is ribosomaly synthesize antimicrobial peptide by gram positive and gram-negative bacteria. Various types of bacteria produce different type of bacteriocins. They have different antimicrobial spectrum. Spectrum of antimicrobial activity varies from bacteria to bacteria. Due to their proteinaceous nature they are harmless to human gastrointestinal tract. Bacteriocins are used to treat many infectious diseases in animals and human beings. It has wide application in food industry to prevent the growth of pathogenic bacteria. Nisin was the first bacteriocin used in the food as the research advances novel bacteriocins introduced which are being used in food industry for the preservation of food. Moreover, it has wide application in pharmaceutical industry. Bacteriocins are gaining attention in the recent era due to their unique mode of antimicrobial action and wide application in various industries.

Keywords: Antimicrobial activity; Antimicrobial peptide; Bacteriocin and pathogenic bacteria

\section{Introduction}

Food spoilage due to microbial adhesion is a great problem. Due to food spoilage there is not only a nutritional loss but also an economical loss [1]. Chemical preservatives are not appropriate due to their hazardous effects on human health. It is very important to resolve this problem to fulfill the food requirement of rising world. In this era, natural and microbiological methods are being used to preserve the food [2]. To manage the economic loss, use of bacteriocins as preservative in the food industries is a satisfactory approach. In the recent world, bacteriocins application are gaining interest as they are generally regarded as safe (GRAS) by the food authority and World health organization [3]. 
Moreover, bacteriocins due to its proteinaceous nature implies a putative degradation in gastrointestinal tract of human beings [4] therefore, these bacteriocins aid colonization in the digestive system [5]. Function of peptides can be affected by various factors including proteolytic degradation, non-polar and polar food components and fat contents, sodium chloride concentration and $\mathrm{pH}[6]$.

Bacteriocins are not only effective against the closely related organisms but also effective against organisms like mycobacterium, viruses and fungi. Its potential applications have been studied specially in food industry as bio preservative from many years [7], [8]. Moreover, bacteriocin as an antimicrobial agent has been exploited in various fields as their influence against various pathogen related to veterinary and human disease [9], [10], [11].

\section{Background of bacteriocins}

It was first reported in 1925, that the antibacterial substance produced by the E. coli have capacity to inhibit the other strains of same species reported by André Gratia [12]. It was thought that the compound produced from bacteria called colicin and are responsible for the inhibitory effect. After that in 1928, it was observed certain Lactococci strains ability to inhibit other LAB strains [13]. According to Mattick and Hirsh, studies in 1947 [14], Lactococcus lactis subsp. Lactis produced an inhibitory substance which called as nisin which has inhibitory effect on prokaryotes [15]. In 1953, nisin was initially marketed, purified and termed as bacteriocin [16] and regarded as safe Food Additives in 1969 by the Joint / World Health Organization Expert Committee/ Food and Agriculture Organization. In the list of food additives, nisin was added in Europe in 1983 and it was used in processed cheese authorized by the American Food and Drug Administration (FDA) in 1988 [17]. Firstly, nisin was approved to be used in food by FDA while as the research advances pediocin have also been used in industrialized foods as preservative obtained from Pediococcus parvulus, Pediococcus acidilactici and Lactobacillus plantarum WHE92 [18]. As reported by Yi [19] Lactobacillus crustorum MN047 synthesize a bacteriocin BMP11 which has a rich $\alpha$-helix confirmation. Bacteriocin was purified through HPLC (high performance liquid chromatography) and ion exchange chromatography and when it tested against food borne pathogen showed minimum inhibitory concentration MIC value of $0.3-38.4 \mu \mathrm{g} / \mathrm{ml}$. Moreover, it was noted that BMP11 had a bactericidal mode of action. Transmission electron microscope and scanning electron microscope (SEM) results showed that BMP11 destroyed the pathogen cell envelop integrity with cell membrane permeability ad cell wall perforation. Cells envelop integrity destruction further identified through lactic dehydrogenase release and propidium (PI) uptake. Meanwhile, in milk it inhibits the growth of Listeria monocytogen and exhibits the antibiofilm formation activity. Therefore, BMP11 has a potential to act as antimicrobial and used as preservative to control the foodborne pathogen in dairy product [19].

\section{Classes of bacteriocins}

The heterogenous group which are peptides synthesized ribosomally [3] mainly divided into three classes, I II and III [20] but advanced studies further categories them into further classes and subclasses. They are classified on the basis of their structural and physiochemical properties. Recently bacteriocins have been divided into four categories. Class I bacteriocins, the lentibiotics [21] are broad spectrum peptides like nisin; inhibit the growth of gram-positive spoilage microbes and food borne pathogens. Class II bacteriocins are the small heat stable non lantibiotics which have narrow antimicrobial spectrum. Garviecin LG34 is a 
class II bacteriocin consisting of 46 amino acid residues which exhibit inhibitory activity against gram negative and grampositive bacteria. Enterocin CRL35 is another class II bacteriocin with anti-Listerial activity [6], [22]. Class III bacteriocins are large heat labile, break down the cell wall of bacteria in an enzymatic manner and are usually endopeptidase. Class IV bacteriocins are composed of lipids, carbohydrates and an undefined mixture of protein [21]. Class IV bacteriocins are complex bacteriocins and are sensitive to lipolytic and glycolytic enzymes like leuconocin $\mathrm{S}$ and plantaricin $\mathrm{S}$.

\section{Mode of action of bacterial bacteriocins}

Antimicrobial peptides produced by prokaryotes that kills or inhibit phylogenetic related microorganisms are called bacteriocins [23]. The action of bacteriocins may be as antimicrobial, colonizing or signaling peptides [24]. They mostly form pores on the cell membrane of pathogen whereas their proteinaceous nature let them degrade efficiently and rapidly. Thus, the chance of developing resistance like antibiotics become minimized [22]. Lactic Acid Bacteria (LAB) are studied extensively due to their potential in bio-preservation by producing bacteriocins $[8,24]$. It has been predicted that $99 \%$ of all bacteria synthesize at least one bacteriocin, with a length of minimum10 amino acids or as long as 688 residues [25]. However, due to multidrug resistance of bacterial clinical strains, the use and application of bacteriocins is gaining more interest [23]. Since the past decade, the reported bacteriocin number has been increased significantly. The high potential of these antimicrobial peptides has expended uses in the pharmaceutical and food industries, in apiculture and agriculture [23, 26]. In recent years, attention is given towards these antimicrobial compounds as they are significant as bio-preservative and substituted for chemical preservatives used in food. They have potential to improve the shelf life of food as well. The equilibrium is attained by their inhibitory activity upon pathogenic bacteria [21].

Different types of bacteria produce different types of bacteriocins that make them distinct from other species of bacteria. Bacteriocins synthesized by LAB (Lactic Acid Bacteria) have variable spectrum of activities. Many bacteriocins are small sized molecules with high isoelectronic points and amphipathic characteristics [27]. The cell produces bacteriocins have specific immunity proteins due to which they are resistant to these antimicrobial peptides [24, 27-29]. LAB (Lactic acid bacteria) are very crucial as they prevent the growth of pathogenic [30] as well as spoilage microbes in food product through the production of acids and antimicrobial agent thus improve the quality and safety of fermented foods [7, 31, 32]. Two LAB species Lactobacillus sakei and Lactobacillus curvatus plays significant role in the accelerated maturation of fermented meat products and improve flavor. These two species are present in a variety of fermented meat products as their microbiota.

The action of bacteriocin is similar that they replace the structural protein or by bacteriocin antagonistic competition for the receptor $[7,33]$. A recent study revealed that the bacteriocin receptor altered with the bacterial membrane structural modifications [34]. Moreover, it was noticed that the additive used with bacteriocin significantly increases it activity [35]. Various classes of bacteriocins have different mode of actions and functions. Functions of class I bacteriocins are to disrupt the membrane of the target (pathogens) by interaction of the peptide with the chiral receptor [36], they are ribosomally produced and post translational peptides (RiPPs), during their biosynthesis they undergo enzymatic modification [3]. In case of class II, cleave the peptide tab. or membrane translocation is facilitated by accessory proteins. 


\section{Biosynthesis of bacteriocins}

Functional analysis of bacterial genome of bacteriocins producing bacteria revealed that the cluster of genes are located on their chromosomes or carried on plasmids. These encoded proteins are responsible for the biosynthesis of these peptides [37]. Microorganisms synthesize the bacteriocins usually in inactive form (pre-peptides) and they have sequence guide at $\mathrm{N}$-terminal [38]. In class II bactriocin family contain conserved motif 'YGNGVXC' on Nterminal [39]. They have a covalent linkage to form their peptide backbone [37]. The precursor (pre-peptides) synthesized during the bacterial exponential growth phase and transported to cell surface and converted to active form enzymatically. The carrier contains two terminals $\mathrm{C}$ and $\mathrm{N}$ (peptidic portion), C portion responsible for energy supply and ATP hydrolysis while guide peptide cleavage on $\mathrm{N}$ terminal [40]. Accessory proteins facilitate the cleavage of peptide or help in membrane translocation. Three components a response regulator, an inducing peptide (or pheromone-activating factor) and the transmembrane histadine kinase (pheromone receptor) are involved in regulating the bacteriocin production system [41]. The ribosome synthesizes the inducer peptide which is secreted in the external environment, outside the cell and cleaved by the carrier system [7]. Transmembrane histadine kinase is activated when the threshold concentration of compound (inducer peptide) is reached, that leads to the histidine residues autophosphorylation, thus phosphate is transferred to a response regulator protein [7]. Bacteriocin transcription is activated by the phosphorylated regulator (sigma factor sigX) [42]. The positive feedback is initiated by the regulatory system [41] and bacteriocins itself act as pheromone and regulated the production of Lantibiotics like subilin and nisin, at high level [43].

\section{Microbial sources of bacteriocin}

Bacteriocin producing bacteria can be isolated from different ecological sources like water, food (yogurt and milk), stool sample (healthy infants), soil and clinical samples. From these samples approximately $54.3 \%$ have ability to produce bacteriocin [44]. Furthermore, bacteriocin producing bacteria have been reported to be isolated from malt [45], fermented food products [46], traditional Chinese fermented cucumber [47], meat [48], gastrointestinal tract of chicken [49], traditional Ethiopian fermented beverages [50], chicken ceca [51], Tibetan kefir [52], human, porcine, and avian gastro intestinal tracts (GIT) [53], marine biofilm forming bacteria [54], poultry products [55], fermented meat and fish products [56], molasses [57], fermented fish roe [58], fermented meat [59], fermented food [60], Sturgeon (popular Italian fish), koumiss [61], natural fermented cream [62] and flounder, cutlassfish, sea bass and turbot [30].

Some important species which produce bacteriocin are Lactobacillus amylovorus DCE 471 [63], Lactococcus lactis subsp. Lactis [55], Lactobacillus plantarum [64], Lactobacillus [50], Lactobacillus salivarius [51], Lactobacillus paracasei subsp. Tolerans [52], Lactococcus garvieae LG34 [47], Lactobacillus crustorum MN047 [61], Lactobacillus alimentarius [48], Lactobacillus casei [60] and Lactobacillus plantarum [30].

Some bacterial species that have been reported to produce bacteriocins are: Pediococcus acidilactici [45], Enterococcus faecium C1 [46], Enterococcus faecalis [49], Pediococcus spp [65], W. cibaria N23 [56], E. faecium CN-25 [58], Lactobacillus spp, Lactococcus spp, Enterococcus spp. or Pediococcus spp [59], Enterococcus faecalis LD33 [62], Bifidobacterium animals BB04 
[66], Haemophilus haemolyticus [67] and Bacillus subtilis SN7 [68].

Bacteriocins: A natural way to combat with pathogens

Bateriocins are the peptides which interfere with the structural proteins of the target pathogen. The interaction of various classes of bacteriocins with its target is diverse. However, the conjugation of bacteriocins with the incorporation of drug delivery system is recently expanding field [69]. Bacteriocin is considered as "designer's drugs" that means they attack on specific pathogen [70]. Bacteriocins have ability to tolerate acidic condition in acidic environment of gastrointestinal tract GIT. It can be applied to control the growth of lethal microorganisms like L. monocytogen. However, in Amado study [71] it was reported that the use of bacteriocin (pediocin SA-1) have ability to inhibit the growth of $L$. monocytogen while enhancing the fermentation quality by promoting the growth of spontaneous fermentation and bacterial communities by their aerobic stability [72]. Some bacterial species displayed high potential of synthesizing bacteriocin like Staphylococci, Pseudomonas, Proteus and Lactobacillus. Bacteriocin produced by Pseudomonas aeruginosa SA 188 named as pyocin not respond to lipolytic and proteolytic enzymes. Moreover, metal salts and organic solvents have no effect on bacteriocin production profile [44].

LAB produced bacteriocins are well known for their efficiency against Listeria monocytogenes, which in the last decade is responsible for many food related outbreaks. In current classification of bacteriocins [73], as reported by Vogel [74] a specific class of bacteriocin is dedicated as anti-Listeria activity while there is a serious issue to control Listeria monocytogenes in processed food as they have potential to grow in condition like salt concentration, low $\mathrm{pH}$ and the presence of nutrients applied during the manufacturing of dry fermented product. According to [75] bacteriocin for preservation of food is increased in food industry as it is the technological alternative to chemical preservative. Lactic acid bacteria (LAB) synthesize a vast variety of antimicrobial peptides (bacteriocins) which have significant contribution towards the safety and preservation of fermented foods [76]. Bacteriocins produced by entomopathogenic Bacillus thuringiensis are getting more attention owing to their inhibitory activity against an extensive variety of pathogenic microorganisms [77].

\section{Antibacterial activity}

Various bacteriocin producing bacteria have different antimicrobial spectrum as the bacteriocin produce by different bacteria have different properties. The antimicrobial spectrum of bacteriocins depends on the structural and physiochemical properties of bacteriocins. Different kinds of bacteria produce different types of bacteriocins like bacteriocin produced by Pediococcus acidilactici strain HW01 have wide antimicrobial activity over a wide range of $\mathrm{pH}(2-11)$ as well as to inhibit a wide range of gram-positive bacteria including pathogenic bacteria like, Streptococcus mutans, Staphylococcus aureus, L. innocua, Listeria monocytogenes and Lactobacillus curvatus [45]. Nisin A inhibits the growth of Listeria monocytogenes [3]. Bacterial species producing bacteriocins against pathogens are shown in (Table 1)

\section{Antifungal activity}

Bacteriocins not only inhibit the growth of bacteria but also inhibit the growth of fungi [78]. Spoilage of food and agricultural commodities due to molds is very significant for causing economic losses. Molds destroying more than thirty percent crops in developing countries while they produce potentially toxic compounds known as mycotoxins which have ability to cause 
illness or death in consumers [79]. According to the study of [80], it was observed that Bacillus subtilis C9 inhibits the growth of plant pathogen Rhizoctonia solani [80]. Furthermore, fungi are ubiquitous in nature and have ability to colonize on various substrates therefore it has high incidence of mycotoxins and molds contamination in food [81]. Lactic acid bacteria (LAB) synthesize a wide variety of secondary metabolites like bacteriocin and organic acids which inhibit microbial growth [82]. Most of Lactic Acid Bacteria reported in past decade as a potential source of antifungal compounds and various studies have showed that various LAB isolates have the significant potential to control the fungi proliferation in many feed and food materials [83-87]. In another study it was reported that the Lactic Acid bacteria have significant potential in preservation of food and used as an antifungal biocontrol agent [88].

\section{Bacteriocin and viruses}

Bacteriocins are also active agent against viruses. All living organisms are majorly affected by pathogens like viruses [89]. They may involve in extensive public health problems e.g; polio virus and its eradiation in developing countries is a challenge $[90,91]$. Moreover, Herpes simplex viruses (HSV) [92] resistant against available antivirals [9395]. Isolation of lactic acid bacteria from goat milk (four Enterococcus durans: GEn17, GEn09, GEn14 and GEn12 and two Lactococcus lactis: GLc05 and GLc03) were tested for cytotoxicity in Vero cells (50\% Cytotoxicity Concentration: CC50), and for their antiviral activities against Poliovirus (PV-1) and Herpes simplex virus 1 (HVS-1) strains. Semi-purified bacteriocins presented low cytotoxicity, with CC50 varying from $256.2 \mu \mathrm{g} / \mathrm{mL}(\mathrm{GLc} 05)$ to $1,084.5 \mu \mathrm{g} / \mathrm{mL}$ (GEn14) [96]. CC10 were determined for all isolates (GLc03: $36.9 \mu \mathrm{g} / \mathrm{mL}$; GLc05: 51.2 $\mu \mathrm{g} / \mathrm{mL}$; GEn09: $88.1 \mu \mathrm{g} / \mathrm{mL}$; GEn12: 99.9 $\mu \mathrm{g} / \mathrm{mL}$; GEn14: $275 \mu \mathrm{g} / \mathrm{mL}$; GEn17: 62.2 $\mu \mathrm{g} / \mathrm{mL}$ ) and considered for antiviral activity assays. Antiviral activity before virus adsorption was noted against HSV-1 for GEn14 (58.7\%), GEn12 (27.9\%), and GEn17 (39.2\%) and against PV-1 for GLc05 (4.9\%), GEn09 (3.4\%), GEn12 (24.7\%) and GEn17 (23.5\%). Antiviral activity after virus adsorption was identified against HSV-1 for GEn17 (71.6\%) and against PV-1 for GLc05 (32.7\%), GEn09 (91.0\%), GEn12 (93.7\%) and GEn17 (57.2\%). The results indicate that some bacteriocins potential in viral inhibition and their application as new antiviral agent, especially these produced by $E$. durans strains [96].

The potential of cell free supernatant and bacteriocins as antiviral agent is very high. It is effective against influenza $A$ virus A/WSN/33 (H1N1), murine norovirus S99 (MNV), feline herpes virus KS 285 and Newcastle disease virus Montana [97]. According to the study of Lange-Starke [97], cell free supernatant of Lactobacillus curvatus strain in 1:10 ratio was effective against $\mathrm{H} 1 \mathrm{~N} 1$ and MNV. Virus reduction was recorded after incubation of 3 days at $24^{\circ} \mathrm{C}$ [97]. The efficacy and safety a subtilosin-based nanofibre formulation have also been evaluated against herpes simplex virus type 1 [98]. Furthermore, it was investigated [99] that the inhibitory activity of a bacteriocin synthesized by a strain of Enterococcus faeciumis able to inhibit the late stages replication of Herpes Simplex Virus (HSV-1 and 55 HSV-2).

\section{Application of bacteriocins}

The applications of bacteriocins increase as the research increases on its structural and functional attributes. With the passage of time the importance of bacteriocin enhanced is due to their significant role in various industries. They have wide application against pathogenic microbes [35], food industry $[2,48]$ agricultural industry [24, 100] veterinary and pharmaceutical industry [24]. 
There is significant application of bacteriocins in food industry as they are used to preserve food. In food industry application of bacteriocins can be classified into three categories: dairy, partially purified bacteriocins and others food grade fermented products [101]. Nisin is a commonly used bacteriocin for the preservation of food in food industry. It is estimated that the nisin which is commonly used in food industry have lethal dose of $6950 \mathrm{mg} / \mathrm{kg}$ [102]. So, the toxicological studies reveal that the nisin has no toxic effect on human health. It is the bacteriocin applied in food industry and has a wide spectrum of antimicrobial activity against pathogens $[2,7]$.

Brochothrix thermosphacta is a grampositive fermenting bacterium. It is a food borne pathogen and decreases the shelf life of packed food [103]. As reported by $\mathrm{Hu}$ [48], bacteriocin producing bacteria Lactobacillus alimentarius FM-MM4 isolated from the fermented meat, exhibited wide range of antimicrobial activity against gram-negative and gram-positive bacteria as well as for yeast [48]. It's a novel bacteriocin produced by the Lactobacillus alimentarius FM-MM4 which is thermostable while exposed to $121{ }^{\circ} \mathrm{C}$ for $15 \mathrm{~min}$ with $84.7 \%$ residual antimicrobial activity. Moreover, it is stable in $\mathrm{pH} 2-5$. As the properties of lactocin indicated that it has significant potential to be used in food industry for the preservation of food [48].

In seafood industry, marine bacteria have been significantly used as probiotic and antibiotics against Mycobacterium, Pasteurella, Streptococcus, Cytophaga, Vibrio and Aeromonas [104, 105, 106]. In food industry, the bacteriocins applied on the surface of sea food in the form of gel and polyethylene film [107]. Thus, to retain the synergistic action bacteriocinogenic strains are used in combination with other preservative and they directly incorporated while packed [108, 109, 110].
Carnobacterium divergens V41 have ability to produce bacteriocin which can be applied on cold-smoked salmon at commercial scale to resist the growth of $L$. monocytogenes [108]. The synergistic effect of various bacteriocins has been proved safe for seafood preservation [111-114].

\section{Agriculture}

Economically important plants have been lost due to phytopathogens. The traditional method to improve the growth of plants like introduction of resistant cultivars and breeding become limited due to genetic resistance. A bacteriocin like colicin can be used to control the growth of phytopathogenic bacteria having a narrow antimicrobial spectrum and can be used as biocontrol in agriculture [100]. Now a days, bacteriocins are also used to preserve the grains [115] and also used to control pest in the field. As reported by Tsuda [116] lactic acid producing bacteria Lactobacillus plantarum strain BY reduced the soft rot disease in Chinese cabbage. This strain is also used to control disease in potato, tomato and onion. After the spray of Lactobacillus plantarum strain BY on Chinese cabbage leave it persisted on wound and inhibit the growth of pathogens while it also proliferates in the host tissue [116]. The results indicated the application of Lactic Acid Bacteria as a biological control as well as biofertilizer in agriculture. They directly promote the seed germination or plant growth and alleviate numerous abiotic stresses [117].

\section{Pharmaceutical industry}

Due to increased antibiotic resistance of pathogens in community there is a need to find out novel antibiotics which are active against multidrug resistance bacteria [56]. Various antimicrobial agent has been introduced like bacteriophages, antimicrobial peptides and bacteriocins etc. [118]. Phages have an antimicrobial activity but they have narrow host rang and phage resistance limits its application while in case of bacteriocin 
applications are wide [55]. Bacteriocins are the most natural and appropriate to be used for pharmaceutical industry [7]. It attacks primarily on the lipid which is necessary for biosynthesis of cell wall. Use it as a docking molecule (lipids II) and thus forms a pore in cell wall. Due to its unique mode of action they are significantly used against most of the drug resistant bacteria [119]. Like it has high influence on drug resistance bacteria, for example, (methicillin resistant Staphylococcus aureus) MRSA and vancomycin resistant enterococci [120]. Bacteriocin also used to treat skin diseases, as the research reported that the bacteriocin neither allergic nor irritating which has been observed in human patch test. The bacteriocin produced by Lactococcus spp. HY 449 is a useful antimicrobial substance to prevent the growth of Propionibacterium acnea and to control acne and skin inflammation [121].

\section{Diagnostic applications of bacteriocins}

Bacterial drug discovery potential of bacteriocins had been well examined [122]. Specificity and affinity of recognizing of necrotic and apoptotic cell is toward phosphatidyl ethanolamine high by the bacteriocin technetium-99m (99mTc) duramycin 123. Biomolecules labelling like protein and DNA by fluorescent or radioactive has been defined [123]. In human peripheral blood Escherichia coli $\mathrm{HSClO}$ produced bacteriocin named as colicin used in the differentiation and detection of leukemic from normal lymphocytes. In flow cytometry studies, bacteriocin affected cell loss the DNA which can be detected by computerized histogram [124]. By labeling of pathogen with nisin, we can study the pathogen mechanisms and pathogen detection has been visualized through fluorescence ratio imaging microscopy [124]. Bacteriocin are also used in the detection of pathogens like bacteria (gram- positive as well as gram-negative), fungi, mycobacterium. Moreover, novel complex bacteriocins in combination with metals used to detect pathogens and other biological analytes [125].

In Pakistan bacteriocins producing bacteria isolated from various indigenous sources like dairy products [126], agricultural soil of Faisalabad [127], fresh and marine water, yoghurt [128]. These antimicrobials were stable at wide range of $\mathrm{pH}$ (3-9) and showed stability on boiling $100^{\circ} \mathrm{C}$ for 3 minutes. They have high potential as a natural preservative [126], biocontrol agent [127], bacteriocinogenic potential against drug resistant bacteria [129] of human and veterinary diseases. Furthermore, bactericidal action of cell wall was observed under electron micrograph [130]. These antagonistic activities of bacteriocins which can be used as a beneficial research tool against pathogenic microorganisms as an antibiotics and useful pharmaceutical products [131].

Table 1. Bacterial species producing bacteriocins against pathogen

\begin{tabular}{|c|c|c|}
\hline Pathogen reported & Bacterial species producing bacteriocin & Reference \\
\hline \multirow{4}{*}{$\begin{array}{c}\text { Listeria monocytogenes } \\
\text { UC8159 }\end{array}$} & $\begin{array}{c}\text { pediocin SA-1 } \\
\text { Pediococcus acidilactici NRRL B-5627, }\end{array}$ & {$[132]$} \\
\cline { 2 - 3 } & $\begin{array}{c}\text { Llarum }(\mathrm{Lb}), \text { L. plantarum }+ \text { L. lactis }(\mathrm{LbL}), \text { L. } \\
\text { plantarum }+ \text { P. acidilactici }(\mathrm{LbP})\end{array}$ & {$[72]$} \\
\cline { 2 - 3 } & LAB (Lactic Acid Bacteria) & {$[\mathbf{5 9}, 72,127]$} \\
\cline { 2 - 3 } & Lactobacillus curvatus 54M16 & {$[132]$} \\
\cline { 2 - 3 } & $\begin{array}{c}\text { Lactobacillus }(\text { L) sakei } \\
\text { Lactobacillus }(L) \text { curvatus }\end{array}$ & {$[133]$} \\
\hline
\end{tabular}




\begin{tabular}{|c|c|c|}
\hline & Enterococcus $($ E) faecium & \\
\hline & Bifidobacterium animals BB04 & {$[66]$} \\
\hline & Enterocin CRL35 class IIa bacteriocin & [34] \\
\hline & Lactobacillus sakei subsp. sakei $2 \mathrm{a}$ & [135] \\
\hline & Lactobacillus crustorum MN047 & [19] \\
\hline \multirow{2}{*}{$\begin{array}{l}\text { L. mono-cytogenes } \\
\text { biofilm formation }\end{array}$} & bacteriocin fromL. plantarum ST8SH & [59] \\
\hline & Lactobacillus paraplantarum FT259 & [136] \\
\hline \multirow{4}{*}{ Escherichia coli } & Lactobacillus crustorum MN047 & {$[61]$} \\
\hline & Weissella hellenica BCC 7239 & [61] \\
\hline & $\begin{array}{c}\text { Lactobacillus plantarum (strains ST194BZ, ST414BZ } \\
\text { and ST664BZ) } \\
\text { Lactobacillus pentosus (strain ST712BZ) } \\
\text { Lactobacillus rhamnosus (strains ST461BZ and } \\
\text { ST462BZ) } \\
\text { Lactobacillus paracasei (strains ST242BZ and } \\
\text { ST284BZ) }\end{array}$ & [61] \\
\hline & Bifidobacterium animals BB04 & {$[66]$} \\
\hline \multirow{2}{*}{ Staphylococcus aureus } & Lactobacillus crustorum MN047 & {$[61,134]$} \\
\hline & Bifidobacterium animals BB04 & {$[66]$} \\
\hline $\begin{array}{l}\text { Pseudomonas } \\
\text { aeruginosa }\end{array}$ & Weissella hellenica BCC 7239 & [137] \\
\hline $\begin{array}{c}\text { Brochotrix } \\
\text { thermosphacta }\end{array}$ & Lactobacillus curvatus 54M16 & [132] \\
\hline Salmonella spp & LAB (lactic acid bacteria) & [134] \\
\hline $\begin{array}{c}\text { Salmonella } \\
\text { Typhimurium } \\
\end{array}$ & Weissella hellenica BCC 7239 & [137] \\
\hline Enterococcus faecalis & $\begin{array}{c}\text { Lactobacillus plantarum (strains ST194BZ, ST414BZ } \\
\text { and ST664BZ) } \\
\text { Lactobacillus pentosus (strain ST712BZ) } \\
\text { Lactobacillus rhamnosus (strains ST461BZ and } \\
\text { ST462BZ) } \\
\text { Lactobacillus paracasei (strains ST242BZ and } \\
\text { ST284BZ) }\end{array}$ & [57] \\
\hline Aeromonas hydrophila, & Weissella hellenica BCC 7239 & [137] \\
\hline Bacillus cerus & Lactobacillus curvatus 54M16 & [132] \\
\hline Campylobacter jejuni & Lactobacillus salivarius & [51] \\
\hline $\begin{array}{l}\text { Pseudomonas } \\
\text { aeruginosa }\end{array}$ & $\begin{array}{c}\text { Lactobacillus plantarum (strains ST194BZ, ST414BZ } \\
\text { and ST664BZ) } \\
\text { Lactobacillus pentosus (strain ST712BZ), } \\
\text { Lactobacillus rhamnosus (strains ST461BZ and } \\
\text { ST462BZ) } \\
\text { Lactobacillus paracasei (strains ST242BZ and } \\
\text { ST284BZ) }\end{array}$ & [57] \\
\hline \multirow{3}{*}{$\begin{array}{l}\text { Gram positive and } \\
\text { gram-negative bacteria }\end{array}$} & Lactococcus garvieae, & {$[47]$} \\
\hline & Bacillus spp & [138] \\
\hline & Enterococcus faecalis & [49] \\
\hline
\end{tabular}




\begin{tabular}{|c|c|c|}
\hline & Lactobacillus paracasei subsp. Tolerans & [52] \\
\hline & Lactobacillus casei (L. casei) & [60] \\
\hline Lactobacillus casei & $\begin{array}{l}\text { Lactobacillus plantarum (strains ST194BZ, ST414BZ } \\
\text { and ST664BZ), Lactobacillus pentosus (strain } \\
\text { ST712BZ), Lactobacillus rhamnosus (strains } \\
\text { ST461BZ and ST462BZ) and Lactobacillus paracasei } \\
\text { (strains ST242BZ and ST284BZ) }\end{array}$ & [57] \\
\hline $\begin{array}{l}\text { Weissella hellenica } \\
\text { BCC } 7293\end{array}$ & $\begin{array}{c}\text { (Listeria monocytogenes and Staphylococcus aureus) } \\
\text { (Pseudomonas aeruginosa, Aeromonas hydrophila } \\
\text { Escherichia coli and Salmonella Typhimurium) }\end{array}$ & [139] \\
\hline Fungi & Lactobacillus paracasei subsp. Tolerans & [52] \\
\hline \multirow{2}{*}{ Yeast } & Bifidobacterium animals BB04 & [66] \\
\hline & Bacillus spp & {$[138]$} \\
\hline
\end{tabular}

\section{Conclusion}

Bacteriocins are the antimicrobial peptides synthesized by bacteria for their survival. These extracellular peptides are very beneficial on industrial scale. They exhibit the ability to inhibit the wide variety of microorganisms. They not only inhibit the growth of closely related bacteria but also have ability to inhibit the growth of viruses and fungus. The ability of bacteria to produce bacteriocin which have inhibitory spectrum might be used for the welfare of human beings and their efficacy in pharmaceutical industries might be exploited by enhancing its production by bacteriocin engineering. However, shifting the antimicrobial spectrum increases potency and stabilization is still a challenging field. Computational approaches to revolutionize the bacteriocin potency through chemical and biological modification are also on way, but more research is needed to explore the behavior and utility of bacteriocin on commercial scale. Future implications of bacteriocins can led to the avenues of innovation for different industries.

\section{Authors' contributions}

Conceived and designed the experiments: Review article idea conceived by: H Hashim, S Sikandar \& AW Qurashi, Analyzed the data: H Hashim, S Sikandar \& AW Qurashi, Contribution tools: H Hashim, S Sikandar, MA Khan \& AW Qurashi, Wrote the paper: H Hashim.

\section{References}

1. Abdullah Q, Mahmoud A, \& Al-harethi A (2016). Isolation and identification of fungal post-harvest rot of some fruits in Yemen. PSM Microbiology 1(1):36-44.

2. Chikindas ML, Weeks R, Drider D, Chistyakov VA, \& Dicks LM (2018). Functions and emerging applications of bacteriocins. Curr Opin Biotechnol. 49: 23-28.

3. Field D, Ross RP \& Hill C (2018). Developing bacteriocins of lactic acid bacteria into next generation biopreservatives. Curr Opin Food Sci 20: 1-6.

4. Altuntas EG (2013). Bacteriocins: A natural way to combat with pathogens. A. Méndez-Vilas, Ed: 1007-1015.

5. Guinane CM, Piper C, Draper LA, O Connor PM, Hill C, Ross R P \& Cotter PD (2015). Impact of environmental factors on bacteriocin promoter activity in gut-derived Lactobacillus salivarius. Appl Environ Microbiol 81(22): 78517859.

6. Mills S, Ross RP, \& Hill C (2017). Bacteriocins and bacteriophage; a narrow-minded approach to food and gut microbiology. FEMS Microbiol Rev 41: 129-153. 
7. Balciunas EM, Martinez FAC, Todorov SD, de Melo Franco BDG, Converti A, $\&$ de Souza ORP (2013). Novel biotechnological applications of bacteriocins: a review. Food Control 32(1): 134-142.

8. Alvarez-Sieiro P, Montalbán-Lopez M, $\mathrm{Mu} \quad \mathrm{D} \quad \& \quad$ Kuipers OP (2016). Bacteriocins of lactic acid bacteria: extending the family. Appl Microbiol Biotechnol 100(7): 2939-2951.

9. Cotter PD, Ross RP \& Hill C (2013). Bacteriocins - a viable alternative to antibiotics?. Nat Rev Microbiol 11(2): 95.

10. Saraiva MAF, Nes IF, Baracat-Pereira MC, de Queiroz MV, Mantovani HC, de Moraes 298 CA (2014). Purification and characterization of a bacteriocin produced by Lactococcus lactis subsp. 299 lactis PD6. 9. J Microbiol Antimicrob 6: 79-87.

11. Yang SC, Lin CH, Sung CT, \& Fang JY (2014). Antibacterial activities of bacteriocins: application in foods and pharmaceuticals. Front Microbiol 5: 241.

12. Radha KR, \& Padmavathi T (2017). Statistical optimization of bacteriocin produced from Lactobacillus del brueckii subsp bulgaricus isolated from yoghurt. Food Res Int: 24(2).

13. da Silva Sabo S, Vitolo M, Gonzalez JMD \& de Souza Oliveira RP (2014). Overview of Lactobacillus plantarum as a promising bacteriocin producer among lactic acid bacteria. Food Res Int 64: 527-536.

14. Mattick ATR, \& Hirsch A (1947). Further observations on an inhibitory substance (nisin) from lactic streptococci. Lancet 5: 5-8.

15. Cotter PD, Hill C \& Ross RP (2005) Food Microbiology: bacteriocins: developing innate immunity for food. Nat Rev Microbiol 3(10): 777.
16. Reeves P (1965). The bacteriocins. Bacteriol rev 29(1): 24.

17. AbdelGhany TM (2015). Safe food additives: a review. $J$ Biol Chem Res 32(1), 402-437.

18. Enan G, El-Essawy AA, Uyttendaele M \& Debevere J (1996). Antibacterial activity of Lactobacillus plantarum UG1 isolated from dry sausage: characterization, production and bactericidal action of plantaricin UG1. Int J Food Microbiol 30(3): 189-215.

19. Yi L, Li X., Luo L, Lu Y, Yan H, Qiao Z, \& Lü X (2018). A novel bacteriocin BMP11 and its antibacterial mechanism on cell envelope of Listeria monocytogenes and Cronobacter sakazakii. Food Control 91: 160-169.

20. Perez RH, Zendo $\mathrm{T}$, \& Sonomoto $\mathrm{K}$ (2014). Novel bacteriocins from lactic acid bacteria (LAB): various structures and applications. Microb Cell Fact: 13(1).

21. Savadogo A, Ouattara AC, Bassole HI, \& Traore SA (2006). Bacteriocins and lactic acid bacteria-a minireview. Afr $J$ Biotechnol 5(9).

22. Ahmad V, Khan MS, Jamal QMS, Alzohairy MA, Al Karaawi MA \& Siddiqui MU (2017). Antimicrobial potential of bacteriocins: in therapy, agriculture and food preservation. Int $J$ Antimicrob Agents 49(1): 1-11.

23. de la Fuente-Salcido NM, CasadosVázquez LE, \& Barboza-Corona JE (2013). Bacteriocins of Bacillus thuringiensis can expand the potential of this bacterium to other areas rather than limit its use only as microbial insecticide. Can J Microbiol 59(8): 515522.

24. Dobson A, Cotter PD, Ross RP, \& Hill C (2012). Bacteriocin production: a probiotic trait?. Appl Environ Microbiol 78(1): 1-6. 
25. Hammami R, Zouhir A, Le Lay C, Hamida JB \& Fliss I (2010). BACTIBASE second release: a database and tool platform for bacteriocin characterization. BMC Microbiol 10(1): 22.

26. Abriouel H, Franz CM, Omar NB, \& Gálvez A (2010). Diversity and applications of Bacillus bacteriocins. Fems Microbiol Rev 35(1):201-232.

27. Nishie M, Nagao JI, \& Sonomoto K (2012). Antibacterial peptides "bacteriocins": an overview of their diverse characteristics and applications. Biocontrol Sci 17(1): 1-16.

28. Deegan LH, Cotter PD, Hill C \& Ross P (2006). Bacteriocins: biological tools for bio-preservation and shelf-life extension. Int Dairy J 16(9): 1058-1071.

29. Mills S, Stanton C, Hill C, \& Ross RP (2011). New developments and applications of bacteriocins and peptides in foods. Annu Rev Food Sci Technol 2: 299-329.

30. Lv X, Ma H, Sun M, Lin Y, Bai F, Li J \& Zhang B (2018). A novel bacteriocin DY4-2 produced by Lactobacillus plantarum from cutlassfish and its application as bio-preservative for the control of Pseudomonas fluorescens in fresh turbot (Scophthalmus maximus) fillets. Food Control 89: 22-31.

31. Fadda S, López C \& Vignolo, G (2010). Role of lactic acid bacteria during meat conditioning and fermentation: peptides generated as sensorial and hygienic biomarkers. Meat Sci 86(1): 66-79.

32. Mangia NP, Trani A, Di Luccia A, Faccia M, Gambacorta G, Fancello F, \& Deiana P (2013). Effect of the use of autochthonous Lactobacillus curvatus, Lactobacillus plantarum and Staphylococcus xylosus strains on microbiological and biochemical properties of the Sardinian fermented sausage. Eur Food Res Technol 236(3): 557-566.

33. Hoffmann A, Schneider T, Pag U \& Sahl HG (2004). Localization and functional analysis of PepI, the immunity peptide of Pep5-producing Staphylococcus epidermidis strain 5. Appl Environ Microbiol 70(6): 3263-3271.

34. Masias E, Dupuy FG, da Silva Sanches PR, Farizano JV, Cilli E, Bellomio A, Saavedra L, Minahk C. (2017). Impairment of the class IIa bacteriocin receptor function and membrane structural changes are associated to enterocin CRL35 high resistance in Listeria monocytogenes. Biochim Biophys Acta 1861(7): 1770-1776.

35. An Y, Wang Y, Liang X, Yi H, Zuo Z, $\mathrm{Xu}, \mathrm{X}$ Zhang, D, Yu, Changqing, \& Han $X$. (2017). Purification and partial characterization of M1-UVs300, a novel bacteriocin produced by Lactobacillus plantarum isolated from fermented sausage. Food Control 81: 211-217.

36. Garneau S, Martin NI, \& Vederas JC (2002). Two-peptide bacteriocins produced by lactic acid bacteria. Biochimie 84(5-6): 577-592.

37. Diep DB, Axelsson L, Grefsli C \& Nes IF (2000). The synthesis of the bacteriocin sakacin A is a temperaturesensitive process regulated by a pheromone peptide through a threecomponent regulatory system. Microbiol 146(9):2155-2160.

38. Macwana S \& Muriana PM (2012). Spontaneous bacteriocin resistance in Listeria monocytogenes as a susceptibility screen for identifying different mechanisms of resistance and modes of action by bacteriocins of lactic acid bacteria. J Microbiol Methods 88(1): 7-13.

39. Kaur R \& Tiwari SK (2018). Membrane-acting bacteriocin purified from a soil isolate Pediococcus 
pentosaceus LB44 shows broad hostrange. Biochem Biophys Res Commun 498(4): 810-816.

40. Aucher W, Lacombe C, Héquet A, Frere J \& Berjeaud J M (2005). Influence of amino acid substitutions in the leader peptide on maturation and secretion of mesentericin Y105 by Leuconostoc mesenteroides. Int J Bacteriol 187(6): 2218-2223.

41. Nes IF, \& Eijsink VGH (1999). Regulation of group II peptide bacteriocin synthesis by quorumsensing mechanisms. Cell-cell signaling in bacteria. ASM Press Washington DC 175.

42. Reck M, Tomasch J, \& Wagner-Döbler I (2015). The alternative sigma factor SigX controls bacteriocin synthesis and competence, the two quorum sensing regulated traits in Streptococcus mutans. PLoS genetics 11(7): 1005353.

43. Kleerebezem M \& Quadri LE (2001). Peptide pheromone-dependent regulation of antimicrobial peptide production in Gram-positive bacteria: a case of multicellular behavior. Peptides 22(10): 1579-1596.

44. Naz SA \& Rasool SA (2013). Isolation, production and characterization of bacteriocins produced by strains from indigenous environments. Pak J Bot 45: 261-267.

45. Ahn H, Kim J \& Kim WJ (2017). Isolation and characterization of bacteriocin-producing Pediococcus acidilactici HW01 from malt and its potential to control beer spoilage lactic acid bacteria. Food Control 80: 59-66.

46. Goh HF \& Philip K (2015). Isolation and mode of action of bacteriocin BacC1 produced by nonpathogenic Enterococcus faecium C1. J Dairy Sci 98(8): 5080-5090.

47. Gao Y, Li D, Liu S, \& Zhang L (2015). Garviecin LG34, a novel bacteriocin produced by Lactococcus garvieae isolated from traditional Chinese fermented cucumber. Food Control 50: 896-900.

48. Hu Y, Liu X, Shan C, Xia X, Wang Y, Dong M \& Zhou J (2017). Novel bacteriocin produced by Lactobacillus alimentarius FM-MM4 from a traditional Chinese fermented meat Nanx Wudl: Purification, identification and antimicrobial characteristics. Food Control 77: 290-297.

49. Hwanhlem N, Ivanova $\mathrm{T}$, Biscola $\mathrm{V}$, Choiset Y \& Haertle T (2017). Bacteriocin producing Enterococcus faecalis isolated from chicken gastrointestinal tract originating from Phitsanulok, Thailand: Isolation, screening, safety evaluation and probiotic properties. Food Control 78: 187-195.

50. Tadesse G, Ephraim E, \& Ashenafi M (2005). Assessment of the antimicrobial activity of lactic acid bacteria isolated from Borde and Shamita, traditional Ethiopian fermented beverages, on some foodborne pathogens and effect of growth medium on the inhibitory activity. Ital J Food Saf 5: 13-20.

51. Messaoudi S, Kergourlay G, Dalgalarrondo M, Choiset Y, Ferchichi M, Prevost H, ... \& Dousset X (2012). Purification and characterization of a new bacteriocin active against Campylobacter produced by Lactobacillus salivarius SMXD51. Food Microbiol 32(1): 129-134.

52. Miao J, Guo H, Ou Y, Liu G, Fang X, Liao Z, Ke, C \& Chen, Y \& Zhao L \& Cao Y (2014). Purification and characterization of bacteriocin $\mathrm{F} 1$, a novel bacteriocin produced by Lactobacillus paracasei subsp. tolerans FX-6 from Tibetan kefir, a traditional fermented milk from Tibet, China. Food Control 42:48-53. 
53. Messaoudi S, Manai M, Kergourlay G, Prévost H, Connil N, Chobert J M, \& Dousset X (2013). Lactobacillus salivarius: bacteriocin and probiotic activity. Food Microbiol 36(2): 296304.

54. Palanichamy S, \& Subramanian G (2017). Antifouling properties of marine bacteriocin incorporated epoxy based paint. Prog Org Coat 103: 33-39.

55. Joerger RD (2003). Alternatives to antibiotics: bacteriocins, antimicrobial peptides and bacteriophages. Poult Sci 82(4): 640-647.

56. Pringsulaka O, Thongngam N, Suwannasai N, Atthakor W, Pothivejkul K, \& Rangsiruji A (2012). Partial characterisation of bacteriocins produced by lactic acid bacteria isolated from Thai fermented meat and fish products. Food control 23(2): 547-551.

57. Todorov SD, \& Dicks LMT (2006). Effect of medium components on bacteriocin production by Lactobacillus plantarum strains ST23LD and ST341LD, isolated from spoiled olive brine. Microbiol Res 161(2): 102-108.

58. Sonsa-Ard N, Rodtong S, Chikindas ML, \& Yongsawatdigul J (2015). Characterization of bacteriocin produced by Enterococcus faecium CN25 isolated from traditionally Thai fermented fish roe. Food Control 54: 308-316.

59. Todorov SD, Perin LM, Carneiro B M, Rahal P, Holzapfel W, \& Nero LA (2017). Safety of Lactobacillus plantarum ST8Sh and its bacteriocin. Probiotics Antimicrob Proteins 9(3): 334-344.

60. Ullah N, Wang X, Wu J, Guo Y, Ge H, Li T, Saleem K, Zhixi L, \& Feng $X$ (2017). Purification and primary characterization of a novel bacteriocin, LiN333, from Lactobacillus casei, an isolate from a Chinese fermented food. LWT - Food Sci. Technol 84: 867-875.

61. Yi L, Dang Y, Wu J, Zhang L, Liu X, Liu B, Zhou Y \& Lu X (2016). Purification and characterization of a novel bacteriocin produced by Lactobacillus crustorum MN047 isolated from koumiss from Xinjiang. China J Dairy Sci 99(9): 7002-7015.

62. Yuehua J, Lanwei Z, Fei L, Huaxi Y, \& Xue H (2016). Complete genome sequence of Enterococcus faecalis LD33, a bacteriocin-producing strain. $J$ Biotechnol 227: 79-80.

63. De Vuyst L, Callewaert R \& Pot B (1996). Characterization of the antagonistic activity of Lactobacillus amylovorus DCE 471 and large scale isolation of its bacteriocin amylovorin L471. Syst Appl Microbiol 19(1): 9-20.

64. Todorov SD, \& Dicks LMT (2005). Lactobacillus plantarum isolated from molasses produces bacteriocins active against Gram-negative bacteria. Enzyme Microb Technol 36(2-3): 318326.

65. Porto MCW, Kuniyoshi T M, Azevedo P O S, Vitolo M, \& Oliveira R P S (2017). Pediococcus spp.: an important genus of lactic acid bacteria and pediocin producers. Biotechnol Adv 35(3): 361-374.

66. Liu G, Ren L, Song Z, Wang C, \& Sun B (2015). Purification and characteristics of bifidocin A, a novel bacteriocin produced by Bifidobacterium animals BB04 from centenarians' intestine. Food control 50: 889-895.

67. Latham RD, Gell DA, Fairbairn RL, Lyons AB, Shukla SD, Cho KY, Jones DA, Harkness NM, Tristram SG. (2017). An isolate of Haemophilus haemolyticus produces a bacteriocinlike substance that inhibits the growth of 
nontypeable Haemophilus influenzae. Int J Antimicrob Agents 49(4): 503-506.

68. Lee SG, \& Chang HC (2018) Purification and characterization of mejucin, a new bacteriocin produced by Bacillus subtilis SN7. LWT- Food Sci. Technol 87: 8-15.

69. Cavera VL, Arthur TD, Kashtanov D \& Chikindas ML (2015). Bacteriocins and their position in the next wave of conventional antibiotics. Int $J$ Antimicrob Agents 46(5): 494-501.

70. Gillor O, Nigro LM \& Riley MA (2005). Genetically engineered bacteriocins and their potential as the next generation of antimicrobials. Curr Pharm Des 11(8): 1067-1075.

71. Amado IR, Fuciños C, Fajardo P, Guerra NP \& Pastrana L (2012). Evaluation of two bacteriocin-producing probiotic lactic acid bacteria as inoculants for controlling Listeria monocytogenes in grass and maize silages. Anim Feed Sci Technol 175(3-4): 137-149.

72. Amado IR, Fuciños C, Fajardo P \& Pastrana L (2016). Pediocin SA-1: A selective bacteriocin for controlling Listeria monocytogenes in maize silages. J Dairy Sci 99(10): 8070-8080.

73. Heng NC, Wescombe PA, Burton JP, Jack RW \& Tagg, JR (2007). The diversity of bacteriocins in Grampositive bacteria. In Bacteriocins. Springer Berlin Heidelberg. pp. 45-92.

74. Vogel BF, Hansen LT, Mordhorst H, \& Gram L (2010). The survival of Listeria monocytogenes during long term desiccation is facilitated by sodium chloride and organic material. Int J Food Microbiol 140(2-3): 192-200.

75. Dickson-Spillmann M, Siegrist M \& Keller C (2011). Attitudes toward chemicals are associated with preference for natural food. Food Qual Prefer 22(1): 149-156.
76. O'Shea, EF, Cotter PD, Ross RP, \& Hill C (2013). Strategies to improve the bacteriocin protection provided by lactic acid bacteria. Curr Opin Biotechnol 24(2) 130-134.

77. Pacheco-Cano RD, Norma M, SalcedoHernández R, León-Galván M F, Bideshi DK., Hernández-Guzmán G, \& Barboza-Corona JE (2014). Characterization, N-terminal sequencing and classification of Tolworthcin 524: a bacteriocin produced by Bacillus thuringiensis subsp. tolworthi. Microbiol Res 169(12): 948-953.

78. Katharopoulos E, Touloupi K \& Touraki M (2016). Monitoring of multiple bacteriocins through a developed dual extraction protocol and comparison of HPLC-DAD with turbidometry as their quantification system. $J$ Microbiol Methods 127: 123-131.

79. Pawlowska AM, Zannini E, Coffey A, \& Arendt EK (2012). "Green preservatives": combating fungi in the food and feed industry by applying antifungal lactic acid bacteria. Adv Food Nutr Res 66: 217-238.

80. Islam M, Jeong YT, Lee YS \& Song CH (2012). Isolation and identification of antifungal compounds from Bacillus subtilis C9 inhibiting the growth of plant pathogenic fungi. Mycobiology 40(1): 59-66.

81. Hassan YI, Zhou T \& Bullerman LB (2016). Sourdough lactic acid bacteria as antifungal and mycotoxin-controlling agents. Food Sci Technol Int 22(1): 7990.

82. Cizeikiene D, Juodeikiene G, Paskevicius A \& Bartkiene E (2013). Antimicrobial activity of lactic acid bacteria against pathogenic and spoilage microorganism isolated from food and their control in wheat bread. Food Control 31(2): 539-545. 
83. Dalié DKD, Deschamps AM, \& Richard-Forget F (2010). Lactic acid bacteria-Potential for control of mould growth and mycotoxins: A review. Food control 21(4): 370-380.

84. Gerez CL, Torino MI, Rollán G \& De Valdez GF (2009). Prevention of bread mould spoilage by using lactic acid bacteria with antifungal properties. Food control 20(2): 144-148.

85. Mauch A, Dal Bello F, Coffey A, \& Arendt EK (2010). The use of Lactobacillus brevis PS1 to in vitro inhibit the outgrowth of Fusarium culmorum and other common Fusarium species found on barley. Int J Food Microbiol 141(1-2): 116-121.

86. Rouse S, Harnett D, Vaughan A, \& Sinderen DV (2008). Lactic acid bacteria with potential to eliminate fungal spoilage in foods. $J$ Appl Microbiol 104(3): 915-923.

87. Dal Bello F, Clarke CI, Ryan LAM, Ulmer H, Schober TJ, Ström K J. Sjögrend D.van Sinderenb J. Schnürerc E.K. Arendt (2007). Improvement of the quality and shelf life of wheat bread by fermentation with the antifungal strain Lactobacillus plantarum FST 1.7. J Cereal Sci 45(3): 309-318.

88. Luz C, Saladino F, Luciano F B, Manes J \& Meca G (2017). In vitro antifungal activity of bioactive peptides produced by Lactobacillus plantarum against Aspergillus parasiticus and Penicillium expansum. LWT. Food Sci. Technol 81: 128-135.

89. ElSawy KM, Twaroc R, Verma CS \& Caves LS (2012). Peptide inhibitors of viral assembly: a novel route to broadspectrum antivirals. J Chem Inf Model 52(3): 770-776.

90. Adekolujo DR, Olayinka SO, Adeniji JA, Oyeyemi OT, \& Odaibo AB (2015). Poliovirus and other enteroviruses in children infected with intestinal parasites in Nigeria. $J$ Infect Dev Ctries 9(10): 1166-1171.

91. Minor PD (2016). An introduction to poliovirus: pathogenesis, vaccination, and the endgame for global eradication. Poliovirus. Methods Protoc: 1-10.

92. James SH, \& Prichard MN (2014). Current and future therapies for herpes simplex virus infections: mechanism of action and drug resistance. Curr Opin Virol 8:54-61.

93. Arita M (2015). Mechanism of poliovirus resistance to host phosphatidylinositol-4 kinase III $\beta$ inhibitor. ACS Infect Dis 2(2): 140-148.

94. Piret J, \& Boivin G (2014). Antiviral drug resistance in herpesviruses other than cytomegalovirus. Rev Med Virol 24(3): 186-218.

95. Soumana DI, Ali A, \& Schiffer CA (2014). Structural analysis of asunaprevir resistance in $\mathrm{HCV}$ NS3/4A protease. ACS Chem Biol 9(11): 24852490.

96. Cavicchioli VQ, de Carvalho OV, de Paiva JC, Todorov SD, Júnior AS \& Nero LA (2018). Inhibition of herpes simplex virus 1 (HSV-1) and poliovirus (PV-1) by bacteriocins from lactococcus lactis subsp. lactis and enterococcus durans strains isolated from goat milk. Int J Antimicrob Agents 51(1): 33-37.

97. Lange-Starke A, Petereit A, Truyen U, Braun P G, Fehlhaber K \& Albert T (2014). Antiviral potential of selected starter cultures, bacteriocins and d, 1lactic acid. Food Environ Virol 6(1): 4247.

98. Torres NI, Noll KS, Xu S, Li J, Huang Q, Sinko PJ, Wachsman MB \& Chikindas ML (2013). Safety, formulation and in vitro antiviral activity of the antimicrobial peptide subtilosin against herpes simplex virus type 1. Probiotics Antimicrob Proteins 5(1): 26-35. 
99. Wachsman MB, Farías ME, Takeda E, Sesma F, de Ruiz Holgado AP, de Torres RA, \& Coto CE (1999). Antiviral activity of enterocin CRL35 against herpesviruses. Int J Antimicrob Agents 12(4): 293-299.

100. Grinter, Rhys, Joel Milner and Daniel Walker (2012). Bacteriocins active against plant pathogenic bacteria. Biochem Soc Trans 40 (6): 1498-1502.

101. Makhal S, Kanawjia SK, \& Giri A (2015). Effect of microGARD on keeping quality of direct acidified Cottage cheese. J Food Sci Technol 52(2): 936-943.

102. Todorov SD, Stojanovski S, Iliev I, Moncheva P, Nero LA, \& Ivanova IV (2017). Technology and safety assessment for lactic acid bacteria isolated from traditional Bulgarian fermented meat product "lukanka". Braz J Microbiol 48(3): 576-586.

103. Stanborough T, Fegan N, Powell SM, Tamplin M, \& Chandry PS (2017). Insight into the genome of Brochothrix thermosphacta, a problematic meat spoilage bacterium. Appl Environ Microbiol 83(5): 02786-16.

104. Galvez A, Lopez RL, Abriouel H, Valdivia E, \& Omar NB (2008). Application of bacteriocins in the control of foodborne pathogenic and spoilage bacteria. Crit Rev Biotechnol 28(2): 125-152.

105. Garcia P, Rodriguez L, Rodriguez A, \& Martinez B (2010). Food biopreservation: promising strategies using bacteriocins, bacteriophages and endolysins. Trends Food Sci Technol 21(8): 373-382.

106. Pilet MF, \& Leroi F (2011). Applications of protective cultures, bacteriocins and bacteriophages in fresh seafood and seafood products. In Protective cultures, antimicrobial metabolites and bacteriophages for food and beverage biopreservation: Woodhead Publishing Series in Food Science.Technology and Nutrition. 324347.

107. Tahiri I, Desbiens M, Kheadr E, Lacroix C, \& Fliss I. (2009). Comparison of different application strategies of divergicin M35 for inactivation of Listeria monocytogenes in cold-smoked wild salmon. Food Microbiol 26(8), 783-793.

108. Brillet A, Pilet MF, Prevost H, Cardinal $M$ \& Leroi F (2005). Effect of inoculation of Carnobacterium divergens V41, a biopreservative strain against Listeria monocytogenes risk, on the microbiological, chemical and sensory quality of cold-smoked salmon. Int J Food Microbiol 104(3):309-324.

109. Gebreyohannes G, Moges F, Sahile S \& Raja N (2013). Isolation and characterization of potential antibiotic producing actinomycetes from water and sediments of Lake Tana, Ethiopia. Asian Pac J Trop Biomed 3(6): 426-435.

110. Schöbitz R, Zaror T, León O, \& Costa M (1999). A bacteriocin from Carnobacterium piscicola for the control of Listeria monocytogenes in vacuumpackaged meat. Food Microbiol 16(3): 249-255.

111. Aasen IM, Markussen S, Møretro T, Katla T, Axelsson L \& Naterstad K (2003). Interactions of the bacteriocins sakacin $\mathrm{P}$ and nisin with food constituents. Int J Food Microbiol 87(12): 35-43.

112. Al-Holy M, Ruiter J, Lin M, Kang DH, \& Rasco B (2004). Inactivation of Listeria innocua in nisin-treated salmon (Oncorhynchus keta) and sturgeon (Acipenser transmontanus) caviar heated by radio frequency. $J$ Food Prot 67(9): 1848-1854.

113. Neetoo H, Ye M, Chen H, Joerger RD, Hicks DT, \& Hoover DG (2008). Use of 
nisin-coated plastic films to control Listera monocytogenes on vacuumpackaged cold-smoked salmon. Int $J$ Food Microbiol 122(1-2): 8-15.

114. Nykänen A, Weckman K, \& Lapveteläinen A (2000). Synergistic inhibition of Listeria monocytogenes on cold-smoked rainbow trout by nisin and sodium lactate. Int J Food Microbiol 61(1): 63-72.

115. Cherif A, Chehimi S, Limem F, Hansen B M, Hendriksen NB, Daffonchio D \& Boudabous A (2003). Detection and characterization of the novel bacteriocin entomocin 9, and safety evaluation of its producer, Bacillus thuringiensis ssp. entomocidus HD9. J Appl Microbiol 95(5): 990-1000.

116. Tsuda K, Tsuji G, Higashiyama M, Ogiyama H, Umemura K, Mitomi M, ... \& Kosaka Y (2016). Biological control of bacterial soft rot in Chinese cabbage by Lactobacillus plantarum strain BY under field conditions. Biol Control 100: 63-69

117. Lamont JR, Wilkins O, BywaterEkegärd M \& Smith DL (2017). From yogurt to yield: Potential applications of lactic acid bacteria in plant production. Soil Biol Biochem 111: 1-9.

118. Rios AC, Moutinho CG, Pinto FC, Del Fiol FS, Jozala A, Chaud MV, Vila MM, Teixeira JA, \& Balcão VM (2016). Alternatives to overcoming bacterial resistances: state-of-the-art. Microbiol Res Journal 191: 51-80.

119. Hathaway H, Ajuebor J, Stephens L, Coffey A, Potter U, Sutton JM \& Jenkins ATA (2017). Thermally triggered release of the bacteriophage endolysin CHAPK and the bacteriocin lysostaphin for the control of methicillin resistant Staphylococcus aureus (MRSA). J Control Release 245: 108115.
120. Nagao JI (2009). Properties and applications of lantibiotics, a class of bacteriocins produced by Gram-positive bacteria. J Oral Biosci 51(3): 158-64.

121. Oh S, Kim SH, Ko Y, Sim JH, Kim K S, Lee S H, Park S \& Kim Y J (2006). Effect of bacteriocin produced by Lactococcus sp. HY 449 on skininflammatory bacteria. Food Chem Toxicol 44(4): 552-559.

122. Uzair B, Ahmeda N, Mohammadb FV, Ahmadb VU, \& Edwards D (2009). Screening of marine bacteria of Pakistan coast for drug discovery potential. Proc. Pakistan Acad. Sci 46(3): 137-144.

123. Imran M, Revol-Junelles AM, de Bruin M, Paris C, Breukink E \& Desobry S (2013). Fluorescent labeling of nisin $\mathrm{Z}$ and assessment of anti-listerial action. $J$ Microbiol Methods 95(2): 107-113.

124. Musclow E \& Farkas-Himsley H (1983). Bacteriocin and flow cytometry in laboratory diagnosis of leukemic peripheral blood lymphocytes and bone marrow cells. Eur J Cancer 19(2): 163171.

125. Olstein AD, \& Feirtag J (2006). U.S. Patent No. 7,034,113. Washington, DC: U.S. Patent and Trademark Office.

126. Shakeel A, Saeed M, Randhawa MA \& Zia MA (2018). Isolation and characterization of bacteriocinogenic lactic acid bacteria from indiginous dairy source and its antimicrobial potential PAK J AGR Sci :55(1).

127. Jabeen N, Gul H., Subhan SA, Hussain M, Ajaz M, \& Rasool SA. (2009). Biophysicochemical characterization of bacteriocin (s) from indigenously isolated Agrobacterium radiobacterNA 6. Pak. J. Bot 41(6): 3227-3237.

128. Rizvi RZ, Wahab A, Pirzada ZA (2014). Screening and identification of aquatic bacteriocinogenic bacillus strains inhibiting clinical methicillin resistant staphylococcus aureus and vancomycin 
resistant enterococcus from Pakistan. Asian J Pharm Clin Res 7(5):53-56.

129. Zahid M, Ashraf M, Arshad M, Muhammad G, Yasmin A, \& Hameed HMA (2015). Antimicrobial activity of bacteriocins isolated from lactic acid bacteria against resistant pathogenic strains. Int J Nutr Fd Sci 4: 326-331.

130. Riaz A, Noureen S, Qamar MF, Liaqat I, Arshad M, \& Arshad N (2018). Characterization of Bacteriocin like Inhibitory Substances from Enterococcus ratti MF183967. Pak Vet $J$.

131. Siraj W (2015). Antipathic and Non Tenacious Effect of Bacteriocin Producing Strains against Pathogenic Organisms. RADS Journal of Biological Research \& Applied Sciences 6(2): 0107.

132. Casaburi A, Di Martino V, Ferranti P, Picariello L, \& Villani F (2016). Technological properties and bacteriocins production by Lactobacillus curvatus 54M16 and its use as starter culture for fermented sausage manufacture. Food Control 59: 31-45.

133. Fontana C, Cocconcelli PS, Vignolo G \& Saavedra L (2015). Occurrence of antilisterial structural bacteriocins genes in meat borne lactic acid bacteria. Food Control 47: 53-59.

134. Swetwiwathana A \& Visessanguan W (2015). Potential of bacteriocinproducing lactic acid bacteria for safety improvements of traditional Thai fermented meat and human health. Meat Sci 109: 101-105.
135. Malheiros PS, Cuccovia IM, \& Franco BD (2016). Inhibition of Listeria monocytogenes in vitro and in goat milk by liposomal nanovesicles containing bacteriocins produced by Lactobacillus sakei subsp. sakei 2a. Food Control 63: 158-164.

136. Winkelströter L K, Tulini F L, \& De Martinis EC (2015). Identification of the bacteriocin produced by cheese isolate Lactobacillus paraplantarum FT259 and its potential influence on Listeria monocytogenes biofilm formation. LWT - Food Sci. Technol 64(2): 586592.

137. Woraprayote W, Pumpuang L, Tosukhowong A, Roytrakul S, Perez $\mathrm{RH}$, Zendo $\mathrm{T}, \ldots$ \& Visessanguan $\mathrm{W}$ (2015). Two putatively novel bacteriocins active against Gramnegative food borne pathogens produced by Weissella hellenica BCC 7293. Food Control 55: 176-184.

138. Compaoré CS, Nielsen DS, Ouoba LI, Berner TS, Nielsen KF, SawadogoLingani $\mathrm{H}$ et al. (2013). Co-production of surfactin and a novel bacteriocin by Bacillus subtilis subsp. subtilis H4 isolated from Bikalga, an African alkaline Hibiscus sabdariffa seed fermented condiment. Int $J$ Food Microbiol 162(3): 297-307.

139. Woraprayote W, Pumpuang L, Tosukhowong A, Zendo T, Sonomoto $\mathrm{K}$, Benjakul $\mathrm{S}$, \& Visessanguan $\mathrm{W}$ (2018). Antimicrobial biodegradable food packaging impregnated with Bacteriocin 7293 for control of pathogenic bacteria in pangasius fish fillets. $L W T$ 89: 427-433. 